\title{
Isolation, structural elucidation, and bioactivity studies of leaf extract of Vernonia Amygdalina
}

\author{
Muluye Melak Zenebe ${ }^{1, ~ *, ~ B i t e w ~ K a s s a w ~ D e s s i e ~}{ }^{1}$, Getachew G/Mariam W/Hana ${ }^{1}$, \\ Adhena Ayaliew Werkneh ${ }^{2}$ \\ ${ }^{1}$ Department of Chemistry, College of Natural and Computational Science, University of Gondar, Gondar, Ethiopia \\ ${ }^{2}$ Department of Chemistry, College of Natural Science, Jigjiga University, Jigjiga, Ethiopia
}

Email address:

muluchem@gmail.com (M. M. Zenebe)

To cite this article:

Muluye Melak Zenebe, Bitew Kassaw Dessie, Getachew G/Mariam W/Hana, Adhena Ayaliew Werkneh. Isolation, Structural Elucidation, and Bioactivity Studies of Leaf Extract of Vernonia Amygdalina. American Journal of Applied Chemistry. Vol. 3, No. 1, 2015, pp. 14-20.

doi: 10.11648/j.ajac.20150301.13

\begin{abstract}
Vernonia Amygdalina (VA) is a tropical African plant of the Asteraceae family and is occasionally cultivated for its medicinal uses, which include as a treatment for diarrhea, skin wounds, fever mastitis and worms infection. The aim of this study is to isolate and elucidate the structure of some of the chemical constituents from the leaf of Vernonia Amygdalina and its bioactivities. The methanol extract of Vernonia Amygdalina, after repeated chromatography led to the isolation of a different compound, one of this compound (MM-4) is partially characterized based on the spectral data (IR, ${ }^{1} \mathrm{H}$ NMR, ${ }^{13} \mathrm{C}$ NMR, and DEPT) and extracts from Vernonia Amygdalina has been shown to have antimicrobial activity.
\end{abstract}

Keywords: Vernonia Amygdalina, Bioactivity, Phytochemical Investigation

\section{Introduction}

Natural products as the term imply 'naturally occurring compounds that are the end products of secondary metabolism and they are unique compounds for particular organism or classes of organisms [1]. Until the 1950's, the structures of natural products were determined by degradative techniques, and a structure was not proven until the compound had been synthesized in an unambiguous manner. Now, structures have been elucidated primarily by spectroscopic techniques, and the stereochemistry is an important feature of the structure [2].

According to [3], the botanical overview of Vernonia Amygdalina belongs to the family Asteraceae that has a rough bark with dense black straits, and elliptic leaves and it is drought resistant, though it grows best in a humid environment. It thrives on a range of ecological zones and is used as a hedge plant in some communities $[4,5,6]$.

Previous studies on phytochemical investigation of the leaves and stem bark of Vernonia amygdalina revealed the presence of secondary metabolites such as Terpinoids. A wide array of phytochemical, including anti-nutritional factors, has been shown to be present in Vernonia amygdalina [7, 8, 9].

Many authors describe the medicinal and biological activity of Vernonia amygdalina $[10,11]$. The leaves of Vernonia amygdalina are crushed to make a paste to be rubbed on the body of livestock for destroying ectoparasites $[12,13]$. It is one of the traditionally used antifertility plants in Ethiopia. Preliminary study also confirmed that the plant has antifertility effect [12]. Earlier investigations on Vernonia amygdalina showed that purified chloroform fractions identified as vernodaline, vernolide and vernomygdine elicited cytotoxic effects on human carcinoma narsopharynx cells [14].

The plant is well known for its antidiabetic and antihypertensive properties. The common and documented medicinal uses include the treatment of schistomiasis, amoebic dysentery, and gastrointestinal problems. It is also used in the treatment of headache, fever, malaria, venereal diseases, wounds, hepatitis, and diabetes $[15,16]$.

In Ethiopia the Plant is used in cleaning the container used for fermentation purpose. The leaves are used for human consumption and washed before eating to get rid of the bitter taste. They are used as vegetable and stimulate the digestive system.

The main aim of this paper is to isolate and elucidate the 
structure of the leaf of Vernonia amygdalina and to study its bioactivities. Further, the paper aims to isolate possible biological active compound (s) from the leaf of Vernonia amygdalina by using various chromatography techniques such as column chromatography and preparative thin layer chromatography. The structure of the active component was elucidated by means of spectroscopic techniques (IRand NMR). Beyond this, the bioactivity of Vernonia amygdalina leaf plant against different pathogens was checked.

\section{Materials and Methods}

\subsection{Sample Collection and Preparation}

The fresh leaves of Vernonia Amygdalina were collected from Gondar, Ethiopia, in October 2013. After the plant material was collected, it was first washed with water to reduce dust particles and then the washed leaves wereairdried at room temperature for a week after which it was ground to a uniform powder \& ready for extraction.

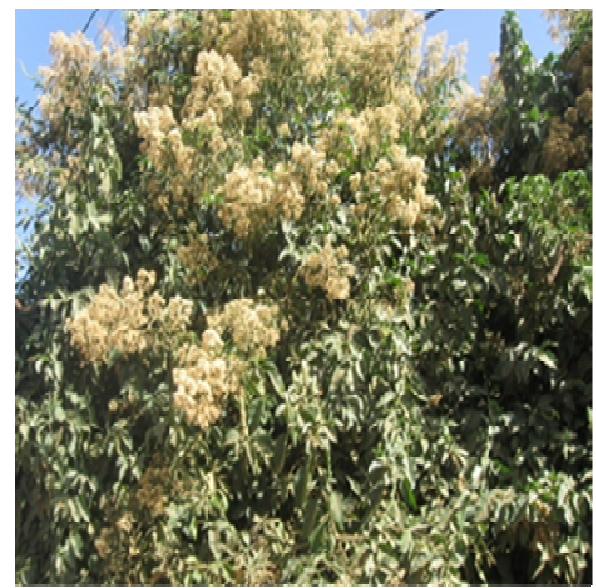

Figure 1. A photograph showing the leaf of Vernonia Amygdalina.

\subsection{Extraction and Isolation}

\subsubsection{Extraction of Plant Materials}

The powder of air dried $(500 \mathrm{~g})$ leaves of Vernonia Amygdalina was first extracted by petroleum ether $(1200 \mathrm{ml})$ then with chloroform and finally the marc after chloroform extraction was extracted with methanol at room temperature. The three extracts were then separately filtered after 24 hoursby Whitman filter paper No.42 (125mm) and the extract were concentrated using a Rotary Evaporator with the water bath set at $60^{\circ} \mathrm{C}$. The yield of the methanol extract was $38 \mathrm{~g}$ jelly solid. The crude part of methanol extract was checked by TLC and then it was subjected to column chromatography gradient elution with petroleum ether / ethyl acetate (2:3).

\subsubsection{Column Chromatography}

A slurry was prepared by mixing $60 \mathrm{gm}$ of silica gel with petroleum ether and then the column was packed with the slurry. Then the methanol extract $(25 \mathrm{mg})$ was applied onto the top of column chromatography and ten fractions were collected by eluting the column with ethyl acetate/ petroleum ether at different proportions as shown in table 1 below.
Table 1. Solvent system used to separate MM-4.

\begin{tabular}{llll}
\hline Fraction & Solvent & Ratio & Amount in ml \\
\hline 1 & Ethyl acetate & $100 \%$ & 20 \\
2 & Pet. ether/ EtOAc & $1: 4$ & 20 \\
3 & Pet. ether/ EtOAc (Further & $2: 3$ & 20 \\
4 & purified with PTLC) & & \\
5 & Pet.ether/ EtOAc & $3: 7$ & 20 \\
6 & Pet. ether/ EtOAc & $1: 9$ & 20 \\
7 & EtOAc/ Pet. Ether & $1: 1$ & 20 \\
8 & EtOAc/ Pet. ether & $2: 1$ & 20 \\
9 & EtOAc/ Pet. ether & $7: 3$ & 20 \\
10 & EtOAc/ Pet. ether & $4: 1$ & 20 \\
\hline
\end{tabular}

The crude extract of methanol was applied on TLC and then the solvent system was changed continuously from petroleum ether/ethyl acetate as shown in Table 1. 10 fractions were collected. Out of these 10 fractions, fraction three which was contained the major component was subjected to further purification by using preparative thin layer chromatography.

\subsubsection{Isolation of Compound by PTLC}

The third fraction (200mg) obtained from column chromatography was dissolved in $10 \mathrm{ml}$ of methanol and applied in the form of aband, on preparative silica gel plates. The solvent system, petroleum ether: ethyl acetate $(2: 3)$ was used as a developing solvent system. The required band (MM-4) was scraped off and collected in a beaker to which methanol was added and filtered.

The filtrate was then concentrated under reduced pressure and the residue was kept in a refrigerator for further work.

\subsubsection{Antimicrobial Activity of Extracts}

The test organisms that were used to check the antimicrobial activity of the crude extract were S.aureus (gram positive), S.boydi (gram negative) and C.alibican (fungus). The antimicrobial activity of crude /purified extracts was determined by using agar well diffusion assay. Muller Hinton Agar Media(MHA) was sterilized at $121^{\circ} \mathrm{C}$ for 15 minutes and then dispensed intoPetridish and allow to cool and placed at $-40^{\circ} \mathrm{C}$. After that the well $(6 \mathrm{~mm}$ diameter) were cut using sterile corn borer on MHA. $1.94 \mathrm{mg} / \mathrm{ml}$ extract was dissolved by chloroform solvent. The 24 hrscultured standard bacteria (shigela boydi $(\mathrm{G})$ and staphylococcus aurous and $48 \mathrm{hrs}$ cultured Candida albicans (clinical isolate) in nutrient broth (NB) was swabbed with a sterilized cotton swab on the surface of prepared Muller Hinton Agar Media (MHA). A 60 $\mu 1$ of thedissolved extract was loaded into each well and left for 30 minutes until the metabolite was diffused. Then the plates were inverted and incubated for $24 \mathrm{~h}$ at $37^{\circ} \mathrm{C}$ for bacteria and $48 \mathrm{hrs}$ at $28^{\circ} \mathrm{C}$ for Candida Albicans. After incubation the zone of inhibition was measured and recorded.

\section{Results and Discussion}

\subsection{Characterization of Compounds}

In order to characterize the compounds isolated from the leaves of Vernonia amygdalina the melting point, the $\mathrm{R}_{\mathrm{F}}$ 
value, and spectroscopic data of the compounds were utilized.

\subsection{Partial Characterization of MM-4}

Compound MM-4was yellowish crystalline material isolated from the leaves of Vernonia amygdalina. It was detected as pinkred spot under a UV lamp and became bluegreen when sprayed with $4 \%$ vanillin $\mathrm{H}_{2} \mathrm{SO}_{4}$. Its $\mathrm{R}_{\mathrm{f}}$ value was 0.19 in petroleum ether/ethyl acetate (2:3) and its melting point was determined to be $160-162^{\circ} \mathrm{C}$. The phytochemical analysis of methanol extract from the leaves of Vernonia amygdalina afforded di-substituted aromatic compounded.

\subsubsection{FTIRSpectral Analysis}

In the FTIR spectrum showedin Fig-7the presence of an aromatic group, the $\mathrm{C}-\mathrm{H}$ stretchabsorption band being at $3019 \mathrm{~cm}^{-1}$, the intense aromatic out of plane bending vibrations of the ring $\mathrm{C}-\mathrm{H}$ bonds, which are most prominent and informative for the presence of aromatic compounds was also observed at $758 \mathrm{~cm}^{-1}$. The spectrum in Fig. 7 also showed the presence of an ester group, the carbonyl absorption band being at $1721 \mathrm{~cm}^{-1}$ and the characteristics intense $\mathrm{C}-\mathrm{O}$ absorption band at $1216 \mathrm{~cm}^{-1}$.

Furthermore the olefinic $\mathrm{C}=\mathrm{C}$ stretch absorption band at $1601 \mathrm{~cm}^{-1}$, the absorption band at $2929 \mathrm{~cm}^{-1}$ indicates the $\mathrm{C}-\mathrm{H}$ stretch of the methyl/methylene groups. The weak N-H stretch absorption band was also observed at $3684 \mathrm{~cm}^{-1}$.

\subsection{2. ${ }^{1}$ H-NMR Spectrum}

The ${ }^{1} \mathrm{H}-\mathrm{NMR}$ spectrumin Fig.4showsthe peak at $\delta$ 0.5-1.18 correspond to the protons of the two methyl groups, which appeared as multiplet due to overlap of signals, the peaks from $\delta 1.28-1.5(\mathrm{~m})$ indicates the signals of the protons of the five methylene groups .The $\mathrm{O}-\mathrm{CH}_{2}$ and the olefinic protons gave signals near $\delta 4.25$ as multipletes. The peak at $\delta 1.75(\mathrm{~m})$ indicate the protons of the methane groups. Furthermore the peaks at $\delta 7.9$ and 8.0 correspond to the protons $1,4-$ substituted aromatic ring.

\subsection{3. ${ }^{13}$ C NMR and DEPT Spectrum}

The proton decoupled ${ }^{13} \mathrm{C}-\mathrm{NMR}$ spectrum in Fig. 5 showed signals of 19 carbon atoms. But in the structure (MM-4) proposed there are 23 carbon atoms. The difference in the number of carbon atoms between the proposed structure and the signals obtained from ${ }^{13} \mathrm{C}$ NMR spectrum might be due to the presence of chemically/magnetically equivalent carbon atoms. As indicated in Fig. 2, carbon atoms $6 \&$ 7', $5 \&$ 6', 3 $\& 3$ ' and $8 \& 15$ might be chemically equivalent.

The (DEPT) spectrum in Fig.6 showed signals for 13 carbon atoms. Out of these 7 signals indicate the presence of 7 methylene groups and the rest 6 signals for $\mathrm{CH}$ and $\mathrm{CH}_{3}$ groups. In DEPT spectrum data are collected in such way that the resulting signal is either positive $\left(\mathrm{CH} \& \mathrm{CH}_{3}\right)$ or negative $\left(\mathrm{CH}_{2}\right)$ depending on the number of protons attached. In the proton decoupled ${ }^{13} \mathrm{C}$ NMR spectrum showed in Fig.5 there are signals for 19 carbon atoms, while in the DEPT spectrum signals were observed for 13 carbon atoms.

The difference in signals between the two spectra indicated the presence of 6 quaternary carbon atoms that are not normally observed in the DEPT spectrum. The ${ }^{13} \mathrm{C}$ and DEPT chemical shifts of the proposed structure are summarized in Table 2 below.

Table 2. ${ }^{13} C \& D E P T$ spectra data of MM-4.

\begin{tabular}{|c|c|c|c|}
\hline No & ${ }^{13} \mathrm{C}$ NMR of MM-4 $\delta$ (ppm) & DEPT & Remark \\
\hline 1 & 65.8 & $\mathrm{O}-\mathrm{CH}_{2}$ & - \\
\hline 2 & 40.7 & $\mathrm{CH}_{2}$ & - \\
\hline 3 & 41.93 & $\mathrm{CH}$ & - \\
\hline 4 & 40.77 & $\mathrm{CH}_{2}$ & - \\
\hline 5 & 147.78 & - & Quaternary carbon \\
\hline 6 & 15.6 & $\mathrm{CH}_{3}$ & - \\
\hline 7 & 112.27 & $\mathrm{CH}_{2}$ & - \\
\hline 8 & 169.6 & - & Quaternary carbon \\
\hline 9 & 128.45 & - & Quaternary carbon \\
\hline 10 & 127.34 & $\mathrm{CH}$ & - \\
\hline 11 & 127.34 & $\mathrm{CH}$ & - \\
\hline 12 & 128.45 & - & Quaternary carbon \\
\hline 13 & 121.73 & $\mathrm{CH}$ & - \\
\hline 14 & 121.73 & $\mathrm{CH}$ & - \\
\hline 15 & 168.74 & - & Quaternary carbon \\
\hline 1 ' & 58.07 & $\mathrm{O}-\mathrm{CH}_{2}$ & - \\
\hline $2^{\prime}$ & 40.49 & $\mathrm{CH}_{2}$ & - \\
\hline 3 ' & 41.93 & $\mathrm{CH}$ & - \\
\hline $4^{\prime}$ & 40.87 & $\mathrm{CH}_{2}$ & - \\
\hline $5^{\prime}$ & 35.24 & $\mathrm{CH}_{2}$ & - \\
\hline $6^{\prime}$ & 147.78 & - & Quaternary carbon \\
\hline 8, & 112.2 & $\mathrm{CH}_{2}$ & - \\
\hline $7^{\prime}$ & 15.6 & $\mathrm{CH}_{3}$ & - \\
\hline
\end{tabular}<smiles>CC(=O)C=CC(N)CC(N)CC(C)OC(=O)c1ccc(C(=O)OC=CC(=O)O)cc1</smiles>

3-amino-5-methylhex-5-enyl 3-amino-6-methylhept-6-enyl terephthalate

Figure 2. The proposed structure of $M M-4$. 


\subsubsection{Antimicrobial Chloroform Extracts}

The antibacterial property of Vernonia amygdalina extract using different solvents showed varying degree of response towards the selected pathogens (Table 3). In this work two samples were tested by the above method. The results showed the crude chloroform extract was strongly active while the pure methanol extract were not active at all against the S. aureus pathogen.

Table 3. Antimicrobial efficacy of extracts against pathogens.

\begin{tabular}{llll}
\hline \multirow{2}{*}{ Extract } & \multicolumn{3}{l}{ Inhibition zone (mm)against pathogens } \\
\cline { 2 - 4 } & $\begin{array}{l}\text { S. aureus ATCC } \\
\mathbf{2 9 2 3}\end{array}$ & $\begin{array}{l}\text { S.boydi } \\
\text { ATCC9289 }\end{array}$ & $\begin{array}{l}\text { C. } \\
\text { albicans }\end{array}$ \\
\hline $\begin{array}{l}\text { 1.Methanol extract } \\
\text { (pure) }\end{array}$ & 0 & 0 & 0 \\
$\begin{array}{l}\text { 2.Chloroform } \\
\text { extract (crude) }\end{array}$ & 30 & 0 & 0 \\
$\begin{array}{l}\text { Tetracycline } \\
\text { Cyclohexamide }\end{array}$ & 21 & 22 & - \\
\hline
\end{tabular}

In this work two samples were tested by the above method. The results showed the crude chloroform extract was strongly active while the pure methanol extract were not active at all against the $S$. aureus pathogen. The outcome of this study has shown that the leaf extract of VernoniaAmygdalinapossesses inhibitory potential against S.aureus while S. boydi were resistant to their activity. The antifungal activities of each of the resulting crude extracts were screened using agar disc diffusion method, but the crude chloroform extract shows a high inhibition zone to the $S$. aureus pathogen. If the extracts were purified, an increase in their antimicrobial activity is likely to be recorded.All of them did not show any inhibition zone to the fungal pathogen.

Generally the extracts showed greater antibacterial activity against gram-positive as compared to gram-negative bacteria. With respect to individual pathogens, the chloroform extract showed greater inhibition than methanol extract.

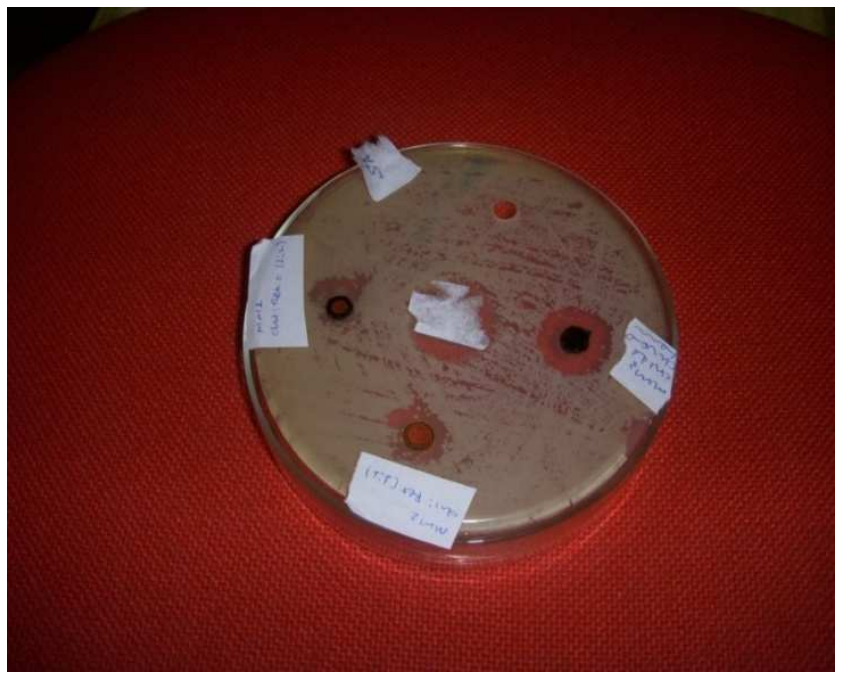

Figure 3. Antimicrobial efficacy of crude chloroform extract against $S$. aureus pathogen.

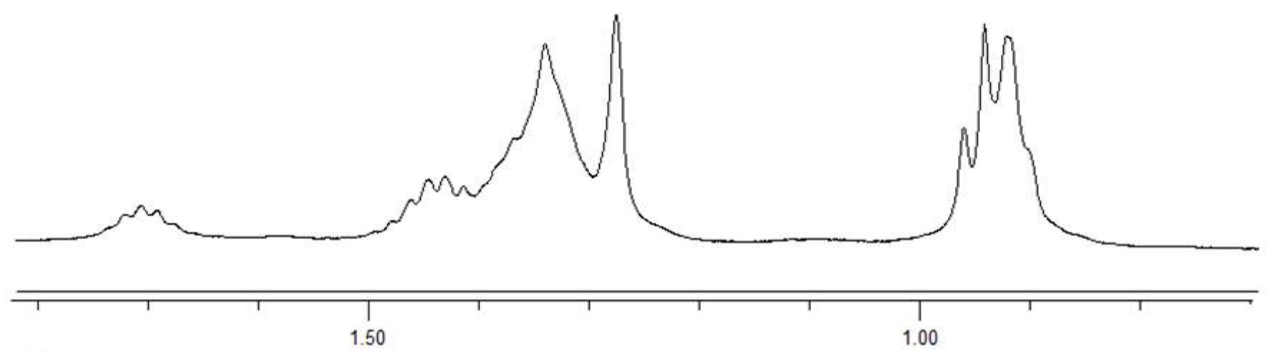

ppm
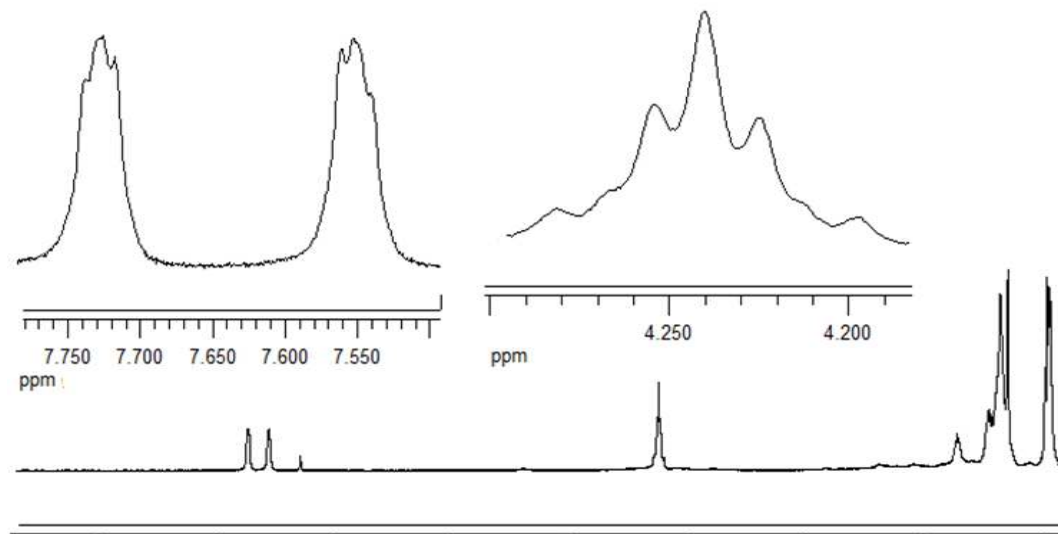

Figure $4 .{ }^{I} H-N M R$. 


$$
\begin{aligned}
& \text { A.A.U Dept. of Chemistry } \\
& \text { NMR Laboratory } \\
& \text { Sample Code: MM-4 } \\
& \text { Book Code: } 91-399 \\
& \text { Date: July-02/2012 } \\
& \text { Experiment: } 13 \mathrm{C} \\
& \text { Solvent: CDCI3 }
\end{aligned}
$$

Solvent

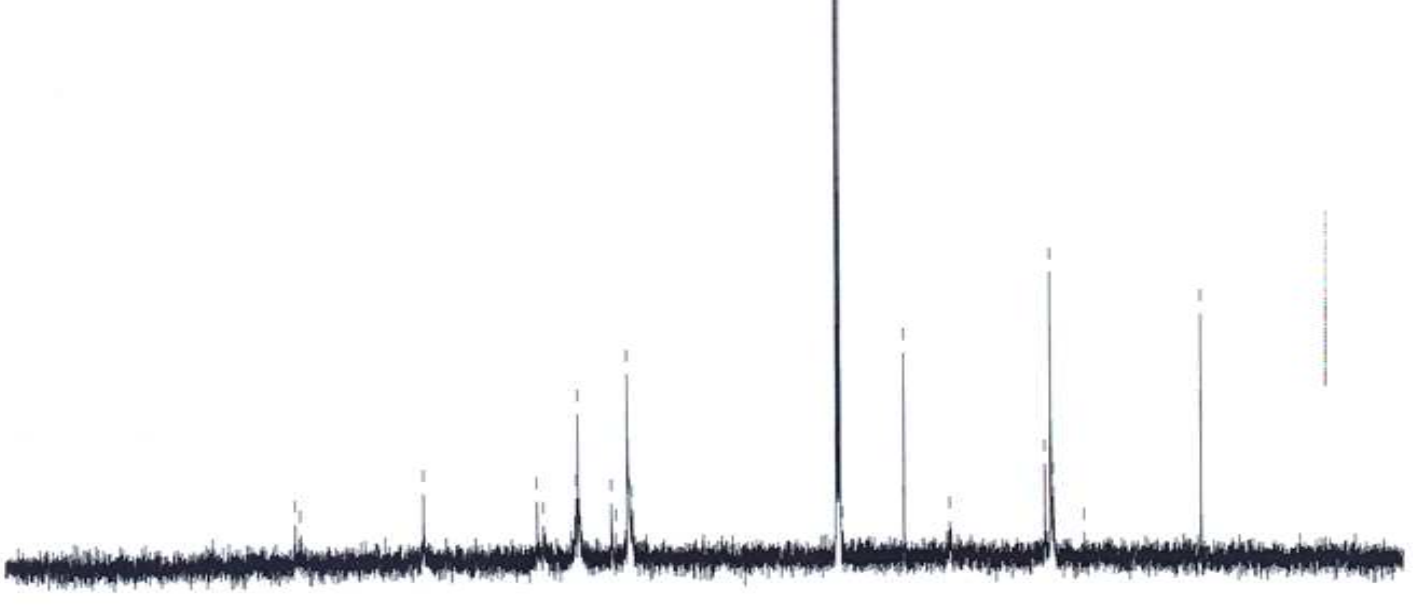

Figure 5. ${ }^{13} C-N M R$ of $M M-4$.

$$
\begin{aligned}
& \text { A.A.U Dept. of Chemistry } \\
& \text { NMR Laboratory } \\
& \text { Sample Code: MM-4 } \\
& \text { Book Code: } 91-399 \\
& \text { Date: July-02/2012 } \\
& \text { Experiment: Dept-135 } \\
& \text { Solvent: CDCl3 }
\end{aligned}
$$




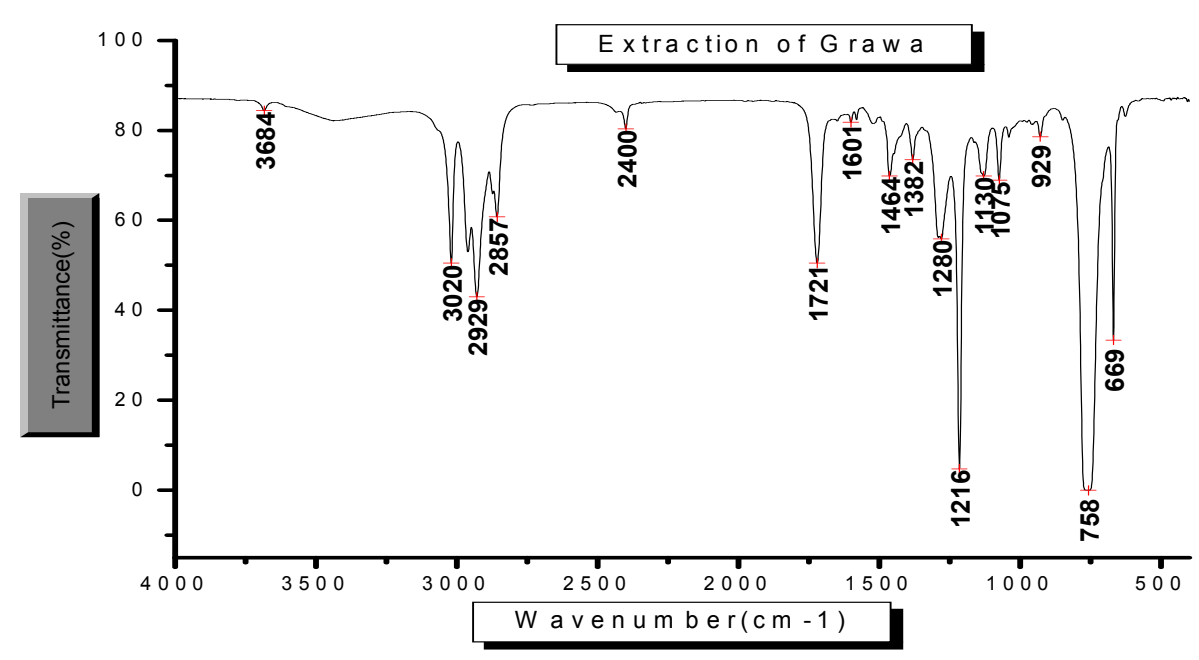

Figure 7. IR spectrum of $M M-4$.

\section{Conclusions}

Phytochemical investigation on the methanol extract of the leaf parts of Vernonia amygdalina afforded one compound; 3-amino-5-methylhex-5-enyl-3-amino-6-methylhept-6-enyl terephthalate. The analyses of the results from bioactivity tests confirm the presence of active compounds which were extracted by chloroform that has a high inhabitation zone of $30 \mathrm{~mm}$. These shows that these compounds are probably the ones most responsible for the well-known effect of the extract of the plant in combating stomach pain.Further works such as structure activity relationships and isolation to identify additional components and determine the mechanism of action of Vernonia Amygdalina compounds would be recommended.

\section{Acknowledgement}

This paper was sponsored by the University of Gondar. I am grateful to Addis Ababa University for their cooperation in the characterization of the sample.

\section{References}

[1] Thomson, R. H. (Ed.). (1993). The chemistry of natural products. Springer.

[2] Khalafalla, M. M., Daffalla, H. M., El-Shemy, H. A., \& Abdellatef, E. (2009). Establishment of in vitro fast-growing normal root culture of Vernonia amygdalina-a potent African medicinal plant. African Journal of Biotechnology, 8(21).

[3] Erasto, P., Grierson, D. S., \&Afolayan, A. J. (2006). Bioactive sesquiterpene lactones from the leaves of $<\mathrm{i}>$ Vernonia amygdalina $</ i>$. Journal of ethnopharmacology, 106(1), 117120.

[4] Havsteen, B. H. (2002). The biochemistry and medical significance of the flavonoids. Pharmacology \& therapeutics, 96(2), 67-202.
[5] Heim, K. E., Tagliaferro, A. R., \&Bobilya, D. J. (2002). Flavonoid antioxidants: chemistry, metabolism and structureactivity relationships. The Journal of nutritional biochemistry, 13(10), 572-584.

[6] Eyong, E. U., Agiang, M. A., Atangwho, I. J., Iwara, I. A., Odey, M. O., \&Ebong, P. E. (2011). Phytochemicals and micronutrients composition of root and stem bark extracts of Vernonia amygdalina Del. Journal of Medicine and Medical Science, 2(6), 900-903.

[7] Awe, S. O., Makinde, J. M., \&Olajide, O. A. (1999). Cathartic effect of the leaf extract of Vernonia amygdalina. Fitoterapia, $70(2), 161-165$.

[8] Oboh, F. O. J., \&Enobhayisobo, E. I.(2009). Effect of aqueous extract of Vernonia amygdalina leaves on plasma lipids of hyperlipidaemic adult male albino New Zealand rabbits, 10 (4).

[9] Yeap, S. K., Ho, W. Y., Beh, B. K., Liang, W. S., Ky, H., Yousr, A. H. N., \&Alitheen, N. B. (2010). Vernonia amygdalina, an ethnoveterinary and ethnomedical used green vegetable with multiple bioactivities. J Medicinal Plants Res, 4, 2787-2812.

[10] Ijeh, I. I., \&Ejike, C. E. (2011). Current perspectives on the medicinal potentials of Vernonia amygdalina Del. Journal of Medicinal Plants Research, 5(7), 1051-1061.

[11] Atangwho, I. J., Ebong, P. E., Eyong, E. U., \&Eteng, M. U. (2010). Combined administration of extracts of Vernonia amygdalina (Del) and Azadirachtaindica (A. Juss) mimic insulin in time-course body weight and glucose regulation in diabetic and non-diabetic rats. Nigerian Journal of Biochemistry and Molecular Biology, 25(1), 44-49.

[12] Asawalam, E. F., Emosairue, S. O., \&Hassanali, A. (2008). Contribution of different constituents to the toxicity of the essential oil constituents of Vernonia amygdalina (Compositae) and Xylopiaaetiopica (Annonaceae) on maize weevil Sitophilus zeamaisMotschulsky (Coleoptera: Curculionidae). African Journal of Biotechnology, 7(16).

[13] Oboh, G. (2006). Nutritive value and haemolytic properties (in vitro) of the leaves of Vernonia amygdalina on human erythrocyte. Nutrition and health, 18(2), 151-160.Alawa, C. B. I., Adamu, A. M., Gefu, J. O., Ajanusi, O. J., 
[14] Abdu, P. A., Chiezey, N. P., \& Bowman, D. D. (2003). In vitro screening of two Nigerian medicinal plants Vernonia amygdalina and Annona senegalensisfor anthelmintic activity. Veterinary Parasitology, 113(1), 73-81.

[15] Oyugi, D. A., Ayorinde, F. O., Gugssa, A., Allen, A., Izevbigie, E. B., Eribo, B., \& Anderson, W. A. (2011). Biological activity and mass spectrometric analysis of Vernonia amygdalina fractions. J Biosci Tech, 2(3), 287-304.

[16] Ayoola, G. A., Coker, H. A., Adesegun, S. A., Adepoju-Bello, A. A., Obaweya, K., Ezennia, E. C., \& Atangbayila, T. O. (2008). Phytochemical screening and antioxidant activities of some selected medicinal plants used for malaria therapy in
Southwestern Nigeria. Tropical Journal of Pharmaceutical Research, 7(3), 1019-1024.

[17] Oboh, F. O., \& Masodje, H. I. (2009). Nutritional and antimicrobial properties of Vernonia amygdalina leaves. Int. $J$. Biomed \& Hlth. Sci, 5(2).

[18] Erasto, P., Grierson, D. S., \& Afolayan, A. J. (2007). Evaluation of antioxidant activity and the fatty acid profile of the leaves of Vernonia amygdalina growing in South Africa. Food chemistry, 104(2), 636-642. 